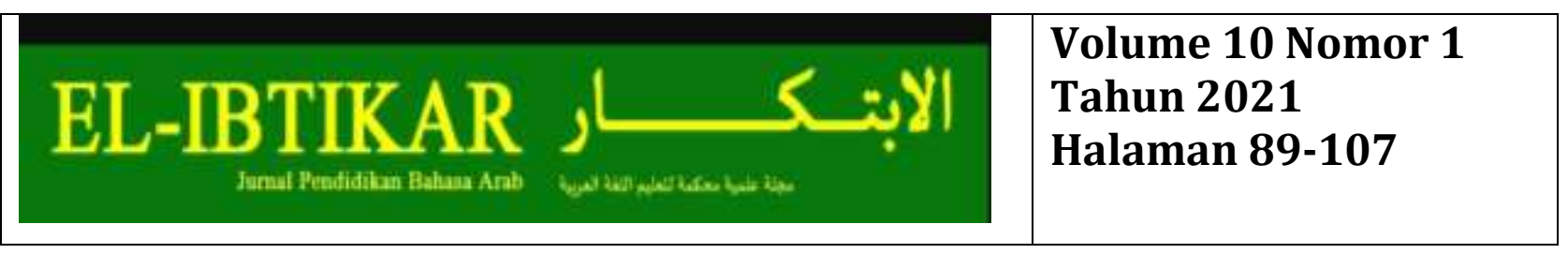

\title{
Manajemen Pembelajaran Bahasa Arab di Madrasah Tsanawiyah Negeri 11 Kabupaten Cirebon
}

\author{
Asep Kurniawan \\ Dosen Pascasarjana Magister Manajemen Pendidikan Islam Institut Agama Islam Negeri \\ Syekh Nurjati Cirebon \\ asepkurniawan@syekhnurjati.ac.id
}

Diterima artikel: 26 Maret 2021

Diterbitkan artikel: 16 Juni 2021

\begin{abstract}
To realize the objectives of learning Arabic, of course, a good Arabic learning management is needed, so the learning objectives can be achieved as much as possible. This article aimed to reveal more about the management of Arabic language learning at Public Islamic Junior High School 11 Cirebon Regency. This study used a descriptive qualitative research approach. Data collection techniques were observation, interviews and documentation. The results showed that the Arabic learning planning was based on the curriculum that had been prepared by the vice principal of the curriculum, the curriculum development team, and the Arabic teachers. The Arabic language learning was included preliminary, core and closing activities. Evaluation was carried out by the principal to evaluate learning strategies. Evaluation of the content of the material was carried out by the vice principal of the curriculum, the curriculum development team and subject teachers at the end of academic year. Meanwhile, the evaluation of student learning outcomes was carried out by the teacher in written and oral exams. In the implementation of learning, there was supporting factor, namely the qualifications of educators. Meanwhile, the inhibiting factors were teachers, students, media and learning methods. The results achieved can be seen from the students' achievements that were already in the sufficient category.
\end{abstract}

Keywords: Management, Learning, Human Resources

\begin{abstract}
Abstrak
Untuk mewujudkan tujuan pembelajaran Bahasa Arab, tentunya diperlukan suatu manajemen pembelajaran Bahasa Arab yang baik, sehingga tujuan pembelajaran itu bisa tercapai semaksimal mungkin. Artikel memiliki tujuan untuk mengungkap lebih jauh tentang manajemen pembelajaran Bahasa Arab. di MTsN 11 Kabupaten Cirebon. Penelitian ini menggunakan pendekatan penelitian kualitatif deskriptif. Tehnik pengumpulan data menggunakan observasi, wawancara dan dokumentasi. Dari hasil penelitian menunjukkan bahwa perencanaan pembelajaran Bahasa Arab mendasarkan pada kurikulum yang telah disusun oleh wakil kepala sekolah bagian kurikulum, tim pengembang kurikulum, dan guru Bahasa Arab. Dalam pelaksanaan pembelajaran Bahasa Arab
\end{abstract}


meliputi pendahuluan, inti dan penutup. Evaluasi dilaksanakan oleh kepala sekolah untuk mengevaluasi strategi pembelajaran, dan evaluasi terhadap isi materi dilaksanakan oleh wakil kepala sekolah bagian kurikulum, tim pengembang kurikulum dan guru mata pelajaran dilaksanakan di akhir tahun, dan evaluasi hasil belajar peserta didik dilaksanakan oleh guru dalam ujian tulis dan lisan. Dalam pelaksanaan pembelajaran ada faktor penunjang yakni kualifikasi pendidik, sedangkan faktor penghambatnya yakni guru, siswa, media dan metode pembelajaran. Hasil yang diraih bisa dilihat dari prestasi siswa yang sudah dalam katogori cukup.

\section{Kata Kunci: Manajemen, Pembelajaran, Sumber Daya Manusia}

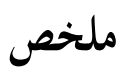

ملتحقيق أهداف تعلم اللغة العربية ، بالطبع ، هناك حاجة إلى إدارة جيدة لتعلم اللغة العربية ، بكيث يمكن تحقيق أهداف التعلم قدر الإمكان. تهدف المقالة إلى الكشف عن المزيد عن إدارة تعلم اللغة العربية. في مدرسة التسناوية الحكمية حي سيريبون تستخدم هذه الدراسة فج البحث النوعي الوصفي. تقنيات جمع البيانات باستخدام المالاحظة والمقابلات والتوثيق. وأظهرت النتائج أن تخطيط تعلم اللغة العربية اعتمد على المنهج الذي أعده نائب مدير قسم المناهج وفريق تطوير المناهج ومعلم اللغة العربية. في تطبيق تعلم اللغة العربية ، يتضمن مقدمة ونواة وختامًا. يتم إجراء التقييم من قبل المدير لتقييم استراتيجيات التعلم ، ويتم تقييم محتوى المادة من قبل نائب مدير قسم المناهج ، ويتم تنفيذ فريق تطوير المناهج ومعلمي المادة في فاية العام ، و يتم تقييم نتائج تعلم الطلاب من قبل المعلم في الاختبارات الكتابية والشفوية. في تنفيذ التعلم ، هناك عوامل داعمة ، وهي المعلمون ، في حين أن العوامل المثبطة هي الطلاب والمعلم وسائل الإعلام وطرق التعلم. وفي الوقت نفسه ، يمكن رؤية النتائج المحققة من خلال تحصيل الطلاب الموجودين بالفعل في الفئة الكافية. الكلمة الرئيسية: الإدارة ، التعلم ، الموارد البشرية

\section{Pendahuluan}

Pembelajaran bahasa sangat dibutuhkan sekali di zaman moderen dewasa ini disebabkan fungsi bahasa itu sebagai instrumen komunikasi. Dengan menguasai bahasa asing, seseorang akan dapat mengungkapkan gagasan, ide atau menulis, membaca, berpikir logis, rasional, sistematik, senantiasa memiliki alternatif, dan bisa berpikir kreatif dan 
inovatif. Roger Trigg secara umum menjelaskan bahwa bahasa sangat erat hubungannya dengan aktivitas berpikir sehingga sistem bahasa yang tidak sama dapat memunculkan pola pikir yang tidak sama pula. Oleh sebab itu, pengaruh Bahasa Arab terhadap banyak bahasa pada masyarakat yang bukan Arab sangat mempengaruhi terhadap cara bersikap dan cara berpikir masyarakat muslim di berbagai penjuru dunia. Bahkan seseorang tidak dapat menjadi ustadz atau ulama yang profesional apabila tidak menguasai Bahasa Arab (Khasanah 2017:2).

Belajar bahasa tidaklah merupakan sesuatu yang mudah, tetapi tidaklah sebaliknya merupakan sesuatu yang sulit. Mudah atau sulitnya mempelajari bahasa tersebut tergantung pada individu yang mempelajarinya itu sendiri, kondisi pembelajaran, dan semua faktor pembelajaran. Inilah persoalan yang dihadapi oleh guru-guru dan lembaga pendidikan, keadaan tersebut disebabkan dari pembelajaran dalam hal ini pembelajaran bahasa bukan hanya sejumlah materi yang banyak dan tuntas. Namun pembelajaran bahasa dituntut pula adanya kebermaknaan. Kebermaknaan ini artinya bahwa proses belajar itu memiliki arti tersendiri bagi para siswa. Jadi bukan hanya "asal belajar" yang pada gilirannya akan bisa menjadi penghubung dalam efektifitas pembelajaran dan pencapaian tujuan secara maksimal.

Di Indonesia, Bahasa Arab memperoleh perhatian yang cukup besar. Fakta tersebut disebabkan sebagian besar penduduk Indonesia adalah muslim. Oleh karena itu, pembelajaran Bahasa Arab di negeri ini sudah tidak asing lagi. Di banyak lembaga pendidikan khususnya madrasah, pesantren dan perguruan tinggi Islam Bahasa Arab diajarkan hampir setiap minggu. Bahkan Bahasa Arab diajarkan setiap saat di banyak kesempatan dan tempat, seperti di masjid melalui belajar membaca al-Qur'an dan membaca kitab kuning di banyak pesantren.

Walaupun begitu, pembelajaran Bahasa Arab masih dinilai belum mencapai hasil yang maksimal untuk dikuasai. Hal tersebut bisa kita lihat dari banyak indikasi, yaitu komunikasi lisan para siswa cenderung tidak fasih dan dipengaruhi bahasa ibu sehingga menjadi Bahasa "Arab ala Indonesia". Demikian pula dengan kemampuan menulis (insya'), Bahasa Arab para siswa masih sulit untuk dimengerti orang lain. Faktor dibalik kegagalan pengajaran Bahasa Arab di Indonesia adalah terutama dari sisi manajemennya, baik itu yang berhubungan dengan kepala sekolah, guru, siswa, kurikulum, metode, dan media 
pengararan maupun evaluasinya (Khasanah 2017, p. 2).

Dalam rangka mewujudkan tujuan pembelajaran Bahasa Arab yang sudah direncanakan oleh suatu lembaga pendidikan khususnya madrasah, tentunya diperlukan suatu manajemen pembelajaran Bahasa Arab yang baik dan selaras dengan arti dari manjemen itu sendiri yang terdiri dari perencanaan, pelaksanaan dan evaluasi sehingga tujuan pembelajaran itu bisa tercapai semaksimal mungkin melalui pemanfaatan sumber daya yang ada secara efektif dan efisien, terutama dalam hal ini guru. Pembelajaran Bahasa Arab yang baik bisa tercipta tergantung bagaimana guru meramu proses pembelajaran (Kesuma, 2017, p. 6; Makruf, 2016, p. 267-280).

Implementasi ilmiah manajemen telah diterapkan di semua bidang kehidupan, terutama dalam konteks artikel ini adalah pembelajaran (Rofiqah et al, 2020, p. 1-8). Hal tersebut dipandang sangat penting untuk mengatur tujuan pendidikan atau pembelajaran. Pendidikan berusaha mendidik kehidupan bangsa (Syatriadin, 2018).

Pengelolaan pembelajaran Bahasa Arab diarahkan untuk mencapai tujuan utama siswa memiliki kemampuan berbahasa yang baik, meliputi keterampilan istima' (menyimak), kalam (berbicara), qira'ah (membaca), dan kitabah (menulis). Mewujudkan manajemen yang baik membutuhkan proses manajemen yang baik untuk semua sumber daya yang tersedia (Raihani, 2016). Salah satu sumber daya yang tersedia adalah guru. Guru sebagai pengelola bertanggung jawab atas seluruh kegiatan perencanaan, pelaksanaan, dan evaluasi proses pembelajaran (Baharuddin, 2014; Nilan, 2009; Ridho, 2018).

Pembelajaran Bahasa Arab yang meaningful learning tentunya sangat diperlukan sekali. Untuk meraih kebermaknaan dibutuhkan manajemen yang sejalan dengan tujuan pembelajaran tersebut. Pada hakekatnya pembelajaran dapat lebih cepat untuk diterima oleh peserta didik apabila memiliki arti bagi mereka. Kebermaknaan dalam pembelajaran Bahasa Arab yang merupakan bahasa asing tentunya lebih membutuhkan upaya ekstra.

Sebagai institusi pendidikan semisal madrasah memiliki peranan yang sangat penting dimana kesuksesan pembelajaran adalah tanggung jawabnya. Untuk itu, manajemen sangatlah diperlukan dan mesti dimiliki oleh semua lembaga pendidikan. Banyak sekali ditemukan permasalahan pembelajaran Bahasa Arab di banyak madrasah. Tujuan dari pembelajaran itu kadang-kadang kurang bisa dicapai secara optimal bahkan ada yang 
pelaksanaannya keluar dari tujuan pembelajaran yang sudah ditetapkan. Hal ini dikarenakan lemahnya manajemen pembelajaran Bahasa Arab, seperti tidak sejalannya materi dan metode yang digunakan.

Penelitian terakhir tentang manajemen pembelajaran bahasa Arab sudah pernah dilakukan, diantaranya penelitian oleh Amirudin et al (2020), dan Badrudin (2017). Penelitian-penelitian tersebut difokuskan untuk mengeksplorasi manajemen pembelajaran bahasa Arab di pesantren atau sekolah berbasis asrama/pesantren yang memiliki karakter berbeda dengan sekolah keagamaan yang tidak berbasis pesantren semisal MTsN 11 Kabupaten Cirebon. Sebab sekolah ini memiliki keterbatasannya yaitu dari kurang intensifikasi pembelajaran Bahasa Arab dibanding dengan siswa yang dari madrasah berbasis pesantren baik dari segi alokasi waktu pembelajaran maupun muatan materi pembelajaran.

Penelitian ini memfokuskan kajiannya pada manajemen pembelajaran Bahasa Arab di MTsN 11 Kabupaten Cirebon, yang meliputi bagaimana perencanaan, pelaksanaan dan evaluasinya, pendukung dan penghambat, serta hasil belajar dari manajemen pembelajaran Bahasa Arab. Subyek dan informan dari penelitian ini terdiri dari kepala sekolah, guru, dan para siswa. Dari sinilah muncul formulasi masalah apakah kemampuan seorang guru dan kepala sekolah dalam melaksanakan manajemen pembelajaran Bahasa Arab dengan baik, sehingga pembelajaran menjadi lebih efektif dan efisien.

\section{Metode Penelitian}

Penelitian ini adalah penelitian kualitatif deskriptif bersifat lapangan dimana peneliti berupaya mendapatkan data dari para pelaku yang diamati baik secara lisan ataupun tertulis (Kurniawan, 2018). Pendekatan ini dipilih sebab peneliti bermaksud untuk memahami, menginterpretasi, dan membangun kembali makna/konsep secara mendalam tentang manajemen pembelajaran Bahasa Arab. Peneliti mencoba menyelidiki secara menyeluruh dengan melakukan eksplorasi lapangan dan pemahaman melalui tinjauan pustaka. Data lapangan adalah salah satunya data utama dalam penelitian ini. Pendekatan yang bersifat analisis deskriptif yang dipilih dalam penelitian ini adalah suatu aktivitas pengumpulan data yang kaya akan fenomena yang ada untuk dianalisis, sehingga didapatkan gambaran utuh terhadap apa yang telah diteliti. Adapun jenis penelitian yang 
digunakan adalah studi kasus, yakni penelitian yang bertujuan untuk mengungkap secara mendalam tentang proses pelaksanaan manajemen pembelajaran Bahasa Arab di MTsN 11 Kabupaten Cirebon. Pelaksanaan penelitian dari mulai Juni sampai Desember 2019. Instrumen pengumpulan menggunakan wawancara, observasi dan dokumentasi. Peneliti mewawancarai kepala sekolah, wakil kepala sekolah bagian kurikulum, guru Bahasa Arab untuk mengetahui manajemen pembelajaran yang relevan dengan topik diskusi sehingga data dapat dihasilkan. Selain itu, wawancara dilakukan dengan siswa sebagai salah satu sampel menggunakan teknik rundown untuk menentukan tanggapan siswa terhadap manajemen pembelajaran Bahasa Arab yang dikembangkan oleh guru. Peneliti juga melakukan observasi secara berkelanjutan. Selain itu peneliti mengambil data melalui dokumentasi tertulis sebagai upaya untuk menentukan jumlah siswa, dokumentasi manajemen pembelajaran bahasa.

Sumber data dalam penelitian ini, yakni para guru, khususnya guru Bahasa Arab di MTsN 11 Kabupaten Cirebon. Informan penting yang lain adalah kepala sekolah, Wakil kepala sekolah bagian kurikulum dan para siswa. Informan atau sampel dalam penelitian ini bersifat purposive karena ingin dipersepsikan secara khusus ditujukan untuk mereka yang terlibat langsung dalam manajemen pembelajaran Bahasa Arab. Jumlah responden 160 siswa. Mereka terdiri dari 120 siswa, 2 orang guru Bahasa Arab, satu orang wakil kepala sekolah bagian kurikulum dan satu kepala sekolah. Teknik analisis data yang digunakan adalah melalui triangulasi data pada sumbernya. Ini dilakukan dalam tiga langkah sistematis; yaitu pengumpulan data, reduksi data dan penarikan kesimpulan. Tambahan, peneliti juga melakukan triangulasi melalui sumber data yaitu menyesuaikan data melalui wawancara, observasi dan dokumentasi. Proses validasi keabsahan data melalui diskusi dengan pakar manajemen pembelajaran Bahasa Arab dan teman sebaya serta guru Bahasa Arab di MTsN 11 Kabupaten Cirebon.

\section{Hasil dan Pembahasan}

\section{Perencanaan Pembelajaran Bahasa Arab}

Perencanaan merupakan diantara fungsi dari tahapan-tahapan proses manajemen, begitu pula dengan perencanaan pembelajaran. Dalam konteks pembelajaran Bahasa Arab 
perencanaan bisa dimaknai sebagai pedoman atau panduan dalam penyusunan program pembelajaran, penyiapan proses pembelajaran, kegiatan penyusunan materi pelajaran, pemanfaatan media pembelajaran, sumber belajar, penerapan pendekatan atau metode pembelajaran, dan penyiapan perangkat penilaian atau evaluasi dalam suatu alokasi waktu tertentu yang akan dilakukan guna mencapai tujuan yang ditetapkan (Andriana, 2015, p. 188) yang mengacu pada standar isi, sehingga memudahkan penyusunan persiapan pembelajaran dan pengembangan pembelajaran PAIKEM. P.P. RI No. 19 tahun 2005 mengenai standar nasional pendidikan pasal 20 menerangkan bahwa "Perencanaan proses pembelajaran mesti mempunyai silabus, perencanaan pelaksanaan pembelajaran yang mengandung setidaknya tujuan pembelajaran, materi ajar, metode pengajaran, sumber belajar, dan evaluasi hasil belajar (Presiden Republik Indonesia, 2005). Perencanaan pembelajaran Bahasa Arab mesti didesain dengan sistematis agar terarah berpedoman kepada silabus kurikulum Bahasa Arab di MTsN 11 Kabupaten Cirebon. Kurikulum adalah dasar dari pemahaman guru untuk menyusun perangkat pembelajaran, selanjutnya penguasaan terhadap konten dari masing-masing pokok bahasan atau bahan ajar adalah syarat mutlak bagi seorang guru guna menyusun dan melakukan manajemen perencanaan pembelajaran.

Perencanaan pembelajaran Bahasa Arab di MTsN 11 Kabupaten Cirebon disusun oleh wakil kepala sekolah bagian kurikulum, tim pengembang kurikulum, dan guru-guru mata pelajaran Bahasa Arab yang dilaksanakan di permulaan tahun yang selanjutnya diimplementasikan dalam proses pembelajaran. Untuk itu, guru dituntut agar mampu mengembangkan kurikulum dan RPP (Rencana Pelaksanaan Pembelajaran) yang telah ada. Penyusunan RPP untuk setiap Kompetensi Dasar yang bisa dilakukan dalam satu kali pertemuan atau lebih. Guru-guru Bahasa Arab membuat RPP untuk semua pertemuan yang diselaraskan dengan jam pelajaran yang tertuang dalam jadwal. Komponen utama dari RPP merupakan tujuan pembelajaran, materi pembelajaran, metode pembelajaran, dan sumber belajar, serta penilaian hasil belajar siswa. RPP dipakai sebagai panduan guru dalam melakukan kegiatan pembelajaran.

Berkaitan dengan kurikulum dalam manajemen pembelajaran yang diselenggarakan di MTsN 11 Kabupaten Cirebon menerapkan kurikulum 2013. Akan tetapi, dalam hal perencanaan pembelajaran guru-guru masih terkadang merasa kesulitan dalam hal 
menyiapkan administrasi kelas seperti penyusunan silabus dan RPP. Apabila dihubungkan dengan pelaksananaan manajemen pembelajaran Bahasa Arab yang diselenggarakan di MTsN 11 Kabupaten Cirebon, bisa dikatagorikan dinilai sedikit belum optimal. Berpijak pada fakta yang ada di lapangan bahwa dari guru-guru Bahasa Arab MTsN 11 Kabupaten Cirebon yang diwawancarai, kadang-kadang guru bahasa Arab tidak menyusun silabus/RPP dalam pertemuan pembelajaran tertentu sebagai panduan bagi perencanaan pembelajaran. Padahal menurut Oviana (2018) dan Afandi \& Badarudin (2011) perencanaan yang disusun dengan baik diikuti dengan rincian yang teliti itu mesti dilaksanakan dengan semaksimal mungkin.

RPP pembelajaran Bahasa Arab di MTsN 11 Kabupaten Cirebon yang standar seperti penilaian pada supervisi kelas, yang mencakup dari pencantuman identitas mata pelajaran (penulisan kelas, mata pelajaran, dan materi, serta alokasi waktu), tujuan pembelajaran (ghordhu khos dan ghordhu 'am), penyelenggaraan pembelajaran: aktivitas pendahuluan, aktivitas inti, aktivitas penutup, dan penandatangan RPP.

Hasil penelitian ini sejalan dengan yang dikemukakan oleh Kabeyi (2019) perencanaan merupakan kegiatan dasar yang diterapkan untuk menetapkan tujuan dan menentukan lingkup pencapaiannya. Merencanakan bermakna mengusahakan pemanfaatan sumber daya manusia, sumber daya alam, dan sumber daya lainnya guna mencapai tujuan. Sejumlah langkah dalam membuat perencanaan pembelajaran sudah dilaksanakan sejalan dengan teori yang dikemukakan Supinah et al (2008) yang menjelaskan bahwa secara teknis rencana pembelajaran setidaknya meliputi sejumlah komponen, yaitu (1) standar kompetensi, dan kompetensi dasar, serta indikator untuk meraih hasil belajar; (2) tujuan pembelajaran; (3) materi pembelajaran; (4) pendekatan dan metode pembelajaran; (5) tahapan aktivitas pembelajaran; (6) alat serta sumber belajar; (7) evaluasi pembelajaran.

Melalui RPP, guru mengharapkan siswanya mampu memiliki empat keterampilan bahasa yang ideal, yaitu keterampilan membaca, menulis, berbicara, dan mendengarkan. Selain bahan yang disiapkan, sebelum belajar Bahasa Arab, media dan metode pembelajaran juga disiapkan, seperti kartu mufrodat, benda-benda di sekitar, bermain peran, tanya jawab, mencari informasi, dan lain-lain.

Sementara itu, proses penyusunan rencana pembelajaran adalah diantara tugas 
penting guru dalam kegiatan pembelajaran. Agar pembelajaran dapat diselenggarakan secara sistematis dan sejalan dengan metode yang akan ditetapkan, perencanaan pembelajaran membutuhkan sejumlah teori untuk mendesainnya agar rencana pembelajaran tersebut bisa tercapai dan mencapai tujuan pembelajaran. Dengan demikian pembuatan rencana pembelajaran adalah diantara faktor yang penting dalam kegiatan pembelajaran. Perencanaan pembelajaran di MTsN 11 Kabupaten Cirebon dimaksudkan guna menghasilkan kemampuan dan meningkatkan keterampilan peserta didik dalam membaca, menulis dan berbicara dalam pembelajaran Bahasa Arab. Untuk mencapai tujuan ini, disamping disusun oleh guru Bahasa Arab, maka akan lebih ideal lagi jika penyusunan RPP tersebut bisa dikonsultasikan dengan wakil kepala sekolah bagian kurikulum atau dengan kepala sekolah itu sendiri. Faktanya hal ini kurang direalisasikan. Padahal menurut Nurul Hidayatul Amalina dan Muh. Nashirudin (2017, p.176) pembuatan RPP seyogyanya disusun secara mandiri oleh guru-guru pengajar, selanjutnya RPP ini dikoreksi atau dikonsultasikan oleh pihak pimpinan atau tim korektor sekolah. Aktivitas tersebut bertujuan guna meminimalisir kekeliruan dalam penyusunan RPP. Kurang aktifnya guruguru Bahasa Arab dalam penyusunan RPP sangatlah berpengaruh terhadap proses pembelajaran, baik dari sisi penyampaian materi ataupun pembagian waktu pada masingmasing pertemuan. Demikian pula dalam penyelenggaraan pembelajaran, gaya guru menyampaikan materi cenderung sedikit monoton, kurang inovatif dan kreatif sehingga kondisi belajar kurang menarik dan menyenangkan (joyful learning).

Tujuan perencanaan pembelajaran disusun oleh wakil kepala sekolah bagian kurikulum, tim pengembang kurikulum, dan guru-guru mata pelajaran Bahasa Arab diawali dengan penyusunan RPP, dan strategi pembelajaran yang akan diterapkan agar seluruh pihak mengetahui dan memahami kegiatan yang sudah disusun lalu diterapkan pada pembelajaran Bahasa Arab. Disamping itu, pengembangan silabus juga dilaksanakan oleh para guru dilaksanakan selain secara mandiri, dilakukan pula secara berkelompok yang lain yaitu dalam aktivitas ini yang dinamakan dengan Musyawarah Guru Mata pelajaran (MGMP). Penyusunan silabus di MTsN 11 Kabupaten Cirebon ini mengacu kapada Peraturan Menteri Pendidikan dan Kebudayaan Republik Indonesia No. 65 Tahun 2013 mengenai Standar Proses Pendidikan Dasar dan Menengah, bab 3 mengenai 
Perencanaan Proses Pembelajaran, menerangkan bahwa silabus adalah pedoman kerangka pembelajaran bagi masing-masing bahan materi mata pelajaran (Menteri Pendidikan dan Kebudayaan R.I., 2013).

Dalam silabus ini hanya meliputi materi-materi pelajaran yang mesti disampaikan dalam waktu setahun atau dalam satu semester. Komponen yang ada dalam silabus, yakni standar kompetensi (SK) dan kompetensi dasar (KD). Standar Kompetensi (SK) yang terdiri dari sekumpulan kompetensi dasar yang mesti dikuasai para siswa. Sedangkan Kompetensi Dasar (KD) yang ditetapkan di madrasah ini adalah sejumlah kemampuan yang mesti dikuasai para siswa dalam mata pelajaran Bahasa Arab sebagai panduan penyusunan indikator kompetensi dalam suatu materi pelajaran yang menyangkut indikator pencapaian kompetensi, tujuan pembelajaran, materi pembelajaran, alokasi waktu, aktivitas pembelajaran, dan penilaian hasil belajar, serta sumber belajar.

Dalam penentuan bahan ajar bagi program pembelajaran Bahasa Arab adalah tahapan berikutnya sesudah penyusunan tujuan perencanaan. Materi pembelajaran Bahasa Arab telah disusun di permulaan tahun ajaran baru dan dirumuskan bersama serta disepakati oleh bagian kurikulum, tim pengembangan kurikulum dan guru-guru mata pelajaran Bahasa Arab, kurikulum yang diterapkan dalam kegiatan pembelajaran Bahasa Arab di MTsN 11 Kabupaten Cirebon adalah kurikulum dari Kementerian Agama RI.

\section{Pelaksanaan Pembelajaran Bahasa Arab}

Jumlah peserta didik pada setiap kelas rata-rata berjumlah 25-30 peserta didik, dan jumlah waktu masing-masing pertemuan yakni 40 menit. Begitu pula dengan buku teks pelajaran, buku yang dipakai untuk mata pelajaran Bahasa Arab adalah terbitan Direktorat KSKK Madrasah Direktorat Jenderal Pendidikan Islam Kementerian Agama Republik Indonesia. Hal tersebut sejalan dengan persyaratan penyelenggaraan proses pembelajaran yang ditetapkan oleh Peraturan Menteri Pendidikan Nasional dan Kebudayaan Republik Indonesia No. 65 Tahun 2013 mengenai Standar Proses Pendidikan Dasar dan Menengah, yang menerangkan bahwa persyaratan dalam penyelenggaraan proses pembelajaran pada masing-masing tingkatan siswa. Bagi siswa SMP/MTs paling banyak jumlah siswa setiap kelas adalah 30 siswa, dan alokasi waktu pada setiap jam pertemuan adalah selama 40 menit. Sumber belajar atau buku teks pelajaran jumlahnya harus diselaraskan dengan 
kebutuhan siswa (Menteri Pendidikan dan Kebudayaan R.I., 2013).

Pelaksanaan pembelajaran Bahasa Arab adalah kegiatan berlangsungnya pembelajaran di kelas yang adalah inti dari aktivitas di sekolah. Jadi pelaksanaan pengajaran Bahasa Arab merupakan interaksi guru dengan peserta didik untuk menyampaikan bahan pelajaran kepada peserta didik dan untuk mencapai tujuan pengajaran.

Pelaksanaan pembelajaran di MTsN 11 Kabupaten Cirebon adalah implementasi dari RPP yang telah disusun, yang di dalamnya terdiri dari bagian pendahuluan, inti dan penutup.

Aktivitas Pendahuluan

Pada permulaan pembelajaran guru-guru pengajar Bahasa Arab mengulas mengenai materi yang hendak disampaikan selama satu semester ke depan sejalan dengan silabus. Selanjutnya di minggu pertemuan berikutnya guru memulai pertemuan dengan menanyakan keadaan/khabar peserta didik, dan mengecek daftar kehadiran. Temuan ini sejalan dengan Peraturan Menteri Pendidikan Nasional dan Kebudayaan Republik Indonesia Nomor 65 Tahun 2013 mengenai Standar Proses Pendidikan Dasar Dan Menengah, Bab IV tentang pelaksanaan pembelajaran. Disana menerangkan bahwa dalam aktivitas pendahuluan hal yang harus diperhatikan guru, yakni menyiapkan para siswa secara fisik dan psikis untuk mengikuti kegiatan pembelajaran dan memberikan motivasi belajar kepada para siswa secara kontekstual sejalan dengan materi yang disampaikan (Menteri Pendidikan dan Kebudayaan R.I., 2013).

Aktivitas inti

Pada aktivitas ini guru-guru Bahasa Arab di MTsN 11 Kabupaten Cirebon memberi feed back secara lisan, yakni menanyakan kepada para siswa hal yang belum difahami dari materi yang disampaikan atau pengetahuan yang lain guna mengembangkan pengertian dan penguasaan para siswa. Dalam proses seperti itulah guru berperan penting menjadi narasumber dan memfasilitasi dalam merespon pertanyaan para siswa. Metode yang diterapkan berpijak pada pedoman buku pegangan guru, namun guru pengajar diberikan kebebasan untuk mengembangkan metode pengajaran.

Proses pembelajaran ini sejalan dengan Peraturan Menteri Pendidikan Nasional dan Kebudayaan Republik Indonesia No. 65 Tahun 2013, yang menerangkan bahwa pada 
aktivitas inti menerapkan model pembelajaran, metode pembelajaran, dan media pembelajaran, serta sumber belajar yang diselaraskan dengan karakteristik para siswa dan mata pelajaran, yang mencakup kegiatan eksplorasi, elaborasi dan konfirmasi (Menteri Pendidikan dan Kebudayaan R.I., 2013).

Aktivitas Penutup

Pada aktivitas penutup ada sejumlah jenis evaluasi yang disampaikan guru pengajar Bahasa Arab di MTsN 11 Kabupaten Cirebon sebelum mengakhiri pembeajaran, antara lain pertanyaan secara lisan, pemberian tugas menjawab soal atau tamrinat, menggunakan sisa waktu yang ada untuk menghafal materi yang baru diajarkan, dan memberi motivasi untuk meningkatkan rasa keingintahuan para siswa terhadap ilmu pengetahuan.

Aktivitas ini sejalan dengan Peraturan Menteri Pendidikan Nasional dan Kebudayaan Republik Indonesia No. 65 Tahun 2013, yang menerangkan bahwa dalam aktivitas penutup guru bersama para siswa, baik secara individual ataupun kelompok melaksanakan sejumlah refleksi untuk mengevaluasi, seperti memberikan feed back terhadap kegiatan dan hasil pembelajaran, melaksanakan aktivitas feed back dalam wujud pemberian tugas, baik tugas secara individu ataupun secara kelompok, dan juga menginformasikan rencana aktivitas pembelajaran untuk pertemuan selanjutnya (Menteri Pendidikan dan Kebudayaan R.I., 2013).

Pelaksanaan pembelajaran sangat erat hubungannya dengan peran guru dalam proses pembelajaran di kelas, yang dapat menentukan terealisasinya tujuan pembelajaran yang telah disusun. Tahapan proses pelaksanaan pembelajaran Bahasa Arab, yakni aktivitas awal ialah pendahuluan yang meliputi pemberian salam, menanyakan kondisi peserta didik, berdoa bersama, selanjutnya guru memotivasi peserta didik agar tetap bersemangat dalam mengikuti proses pembelajaran, diteruskan dengan melaksanakan apersepsi sebagai permulaan komunikasi guru sebelum melakukan pembelajaran inti. Selanjutnya guru menyampaikan aktivitas yang hendak dilaksanakan hari ini dan tujuan yang mau dicapai dari aktivitas tersebut. Aktivitas yang berikutnya adalah pembelajaran inti. Dalam pembelajaran inti ini guru menerangkan materi dan peserta didik menyimaknya, lalu merubah dhomir, memperoleh arti kata, membaca kata, menulis kata, menyusun kalimat, dan diakhiri dengan evaluasi.

Keterampilan mendengarkan dipraktekkan dengan mendengarkan perbedaan dalam 
suara elemen kata (fonem) dengan elemen kata lain menurut huruf makhraj yang benar yang langsung dipraktekkan oleh guru Bahasa Arab. Termasuk latihan mendengarkan ini elemen kata yang dipisahkan dari memahami artinya. Kemampuan mendengarkan adalah keterampilan bahasa yang penting. Setiap siswa dituntut untuk memiliki kemampuan mendengarkan tepat. Pernyataan ini masuk akal karena keterampilan mendengarkan adalah salah satunya kegiatan dalam komunikasi. Tanpa keterampilan mendengarkan yang memadai, bisa dibayangkan betapa sulitnya bagi seseorang untuk melakukannya berkomunikasi dengan orang lain. Lebih khususnya, seseorang tidak akan bisa berbicara dengan orang lain atau menanggapi berbicara tanpa keterampilan mendengarkan. Tanpa keterampilan mendengarkan, akan ada banyak kesalahpahaman dalam komunikasi antara sesama pengguna bahasa yang bisa menyebabkan berbagai kendala dipelaksanaan tugas dan kegiatan sehari-hari.

Pembelajaran keterampilan membaca (Maharat al-Qira'ah) kajian tentang qira'ah dan mutala'ah adalah media untuk melatih keterampilan membaca siswa. Kegiatan tersebut dapat membantu siswa untuk melihat dan memahami isi dari apa yang tertulis. Jadi, keterampilan membaca termasuk dua keterampilan sekaligus, yaitu mengenali simbol tertulis dan pemahaman. Jadi, keterampilan membaca mencakup dua hal keterampilan sekaligus, yaitu mengenali simbol tertulis dan pemahaman isi atau artinya. Kemahiran dalam membaca Bahasa Arab adalah masalah khusus untuk pelajar di Indonesia sekalipun mereka mahir dalam membaca aksara Latin. Bahwa karena alfabet Arab sangat banyak berbeda dengan alfabet latin dimana alfabet Arab memiliki kebebasan tersendiri sistem. Sementara itu, keterampilan menulis atau imla dan berbicara kurang ditekankan.

Adapun media pembelajaran yang dipakai di MTsN 11 Kabupaten Cirebon seperti buku paket, papan tulis, laptop, dan proyektor yang sudah disusun agar bisa dengan mudah dipahami dalam menerangkan agar mempermudah tercapainya tujuan pembelajaran Bahasa Arab. Sebagaimana yang dilaporkan dari hasil Ramzi Baalbaki bahwa eksistensi media pembelajaran dalam proses kegiatan pembelajaran Bahasa Arab berfungsi sebagai pengantar dari pemahaman siswa, dan sangat diperlukan sebagai penjelas dari apa yang sudah disampaikan oleh guru (Baalbaki, 2006).

\section{Evaluasi Pembelajaran Bahasa Arab}


Evaluasi pembelajaran adalah komponen utama dalam kurikulum dan suatu usaha untuk mengungkap melalui pengukuran dan penilaian dari sejauhmana hal-hal yang sudah dimiliki oleh peserta didik dari materi yang sudah diajarkan oleh guru (Idrus 2019). Evaluasi pembelajaran meliputi evaluasi hasil belajar dan evaluasi proses pembelajaran. Evaluasi hasil belajar memfokuskan pada didapatkannya informasi mengenai seberapakah perolehan peserta didik dalam mewujudkan tujuan pengajaran yang ditentukan. Sedangkan evaluasi pembelajaran adalah proses sistematis untuk mendapatkan informasi mengenai keefektifan proses pembelajaran dalam membantu peserta didik mencapai tujuan pengajaran dengan maksimal (Badan Standar Nasional Pendidikan Pendidikan, 2007).

Evaluasi di MTsN 11 Kabupaten Cirebon dilaksanakan oleh guru guna mendapatkan data tentang hasil belajar peserta didik sesudah proses pembelajaran berlangsung. Model evaluasi pembelajaran Bahasa Arab pada evaluasi akhir semester dan akhir tahun untuk mata pelajaran Bahasa Arab ada dua sistem penilaian, yakni lisan dan tulisan. Oleh sebab itu, untuk sistem penilaian pembelajaran Bahasa Arab di MTsN 11 Kabupaten Cirebon, yakni dengan ujian lisan dan tulisan, ditambah dengan nilai UAS (Ujian Tengah Semester), tes formatif dan juga kemahiran peserta didik dalam berbicara Bahasa Arab. Meskipun demikian ujian lisan kurang terlalu ditekankan. Ujian tulis pun lebih banyak kepada tes yang bersifat objektif multiple choice, sehingga hanya mengungkap sisi domain kognitif siswa. Desain evaluasi yang monoton seperti ini pernah diungkapkan oleh Febriani, Wargadinata, dan Adam bahwa keadaan tersebut dikarenakan kompetensi guru dan kapasitas tidak inovatif dalam merancang evaluasi itu sendiri (Febriani et al., 2020). Kurangnya pelatihan dan peningkatan kompetensi berdampak pada proses evaluasi itu belum berkembang (Febriani, et al., 2020b). Intinya, proses evaluasi harus mendeskripsikan siswa hasil belajar yang relevan dengan tujuan pembelajaran yang diinginkan.

Evaluasi dilakukan untuk mengungkap apakah hasil belajar sudah tercapai tidaknya selama satu semester. Evaluasi bahan ajar diselenggarakan setiap akhir tahun oleh waka kurikulum dan tim pengembang kurikulum guna mempersiapkan tahun ajaran baru, terutama silabus, sebab silabus/RPS yang digunakan berpedoman kepada silabus/RPS MTsN 11 Kabupaten Cirebon. 
Evaluasi pelaksanaan pembelajaran dilaksanakan oleh kepala sekolah selaku pimpinan tertinggi di sekolah di mulai dari perencanaan, kepala sekolah dapat meninjau dan mengevaluasi dari RPP strategi apa yang diterapkan, evaluasi guru di kelas dan evaluasi hasil belajar yang dilaksanakan oleh kepala sekolah, sebab evaluasi ini ada hubungannya dengan KKM (Kriteria Ketuntasan Minimal) yang ditetapkan oleh sekolah, sebab kurikulum yang digunakan adalah kurikulum dari Kementerian Agama.

Evaluasi terhadap hasil belajar peserta didik dinilai dari formative test. Evaluasi formatif yang ditujukan untuk membantu meningkatkan kondusifitas dan lingkungan belajar mengajar bagi para siswa yang mana dalam evaluasi formatif tersebut bisa memberikan stimulusasi dan informasi diagnostik permulaan untuk mencapai pencapaian belajar peserta didik yang efektif. Guru semua pertemuan bisa mengetahui rata-rata ketercapaian hasil belajar peserta didik apakah mengalami peningkatan atau malah penurunan. Evaluasi juga diambil dari PAS (Penilaian Akhir Semester). Sementara itu, hasil evaluasi peserta didik dalam pembelajaran Bahasa Arab dalam empat kompetensi peserta didik, yakni kompetensi peserta didik dalam menulis, berbicara, mendengar, dan membaca di kelas, peserta didik menguasai dalam kompetensi menulis dan membaca seperti membaca buku muthola'ah selaras dengan kaidah yang telah dipelajari, dan kompetensi menulis sebab guru acapkali menyuruh peserta didik untuk menulis mufradat baru jadi kompetensi peserta didik dalam menulis meningkat. Meskipun demikian, banyak dari para peserta didik masih menemui kendala dalam mendengar, membaca, dan berbicara sebab mereka masih menemukan kendala dalam menerapkan sejumlah kaidah yang telah dipelajari.

\section{Faktor Pendukung dan Penghambat Pembelajaran Bahasa Arab}

Aktivitas pembelajaran tidak bisa dilepaskan dari faktor pendukung dan penghambat. Faktor pendukung adalah berbagai hal yang mendorong terhadap terlaksananya pembelajaran, sedangkan hambatannya ialah berbagai hal yang terhadap pelaksanaan pembelajaran. Faktor pendukung pembelajaran Bahasa Arab, yakni pendidik. Untuk guru ditinjau dari segi latar belakang pendidikan terakhir dan kualifikasinya, yakni sarjana dengan latar belakang pendidikan Bahasa Arab IAIN sehingga guru-guru disini dinilai memiliki kafasitas profesionalitas yang baik dalam mata pelajaran Bahasa Arab. Dengan 
demikian, guru-guru di MTsN 11 Kabupaten Cirebon cukup menguasai materi pelajaran.

Faktor kendala dalam pembelajaran Bahasa Arab adalah dari faktor guru, siswa dan media pembelajarannya. Dalam hal ini, pelaksanaan pembelajaran, yakni kurang aktifnya guru pengajar Bahasa Arab dalam menanyakan materi yang lalu dan memberikan apersepsi sebelum mengawali atau menambah materi baru, kurangnya koordinasi antara sesama guru Bahasa Arab dan kurangnya informasi tentang pemasalahan selama kegiatan pembelajaran dari guru mata pelajaran yang tidak hadir dalam MGMP (Musyawarah Guru Mata Pelajaran).

Para peserta didik banyak yang kurang berminat dalam mengikuti proses pembelajaran Bahasa Arab sehingga mengakibatkan tujuan pembelajaran tidak dapat terealisasi secara maksimal dan menjadi kendala pembelajaran Bahasa Arab. Sedangkan dalam media pembelajaran adalah sebab media yang dipakai khususnya proyektor yang terbatas jumlahnya sebab mesti bergantian dengan guru lain, sehingga guru mendapatkan kesulitan apabila hendak menggunakan media tersebut.

Selain itu, kendala yang lain adalah pembelajaran Bahasa Arab di MTsN 11 Kabupaten Cirebon pada umumnya belum berhasil memberi keterampilan dan pemahaman berBahasa Arab kepada para para siswa. Mata pelajaran Bahasa Arab lebih banyak diajarkan sekedar sebagai pengetahuan atau ilmu mengenai kebahasaan, bukan sebagai keterampilan berbahasa yang dipakai sebagai instrumen komunikasi. Dampaknya saat para siswa belajar Bahasa Arab tidak lebih dari sekedar mengenalkan Bahasa Arab sebagai ilmu yang lebih banyak mengajarkan aspek tata bahasanya (qowaid) dibandingkan dengan aspek berbicara (kalam). Bahkan, proses pembelajaranpun sangat minim menggunakan Bahasa Arab sebagai bahasa pengantar pembelajaran.

Fenomena pembelajaran Bahasa Arab tersebut sebagai pengetahuan bisa diakibatkan banyak faktor, yaitu guru-guru mendapatkan kesulitan untuk mengajarkan mata pelajaran Bahasa Arab secara langsung komunikasi dengan Bahasa Arab itu sendiri sebab kondisi siswa yang kurang mempunyai dasar Bahasa Arab yang memadai, sehingga mesti diajarkan mulai dari tingkat dasar. Sebagian peserta didik menganggap Bahasa Arab adalah bahasa yang sulit. Faktor anggapan kesulitan ini adalah kurangnya kosa kata yang dimiliki, dan kurang mendukungnya siswa untuk belajar dengan sungguh-sungguh. Penyebab yang lain adalah adanya tuntutan kurikulum yang tidak menekankan penggunaan Bahasa Arab 
sebagai bahasa pengantar pembelajaran, mengakibatkan guru-guru kurang memberikan perhatian pada aspek menulis dan berbicara, namun lebih banyak pada Bahasa Arab reseptif seperti membaca dan mendengar. Kondisi ini pun berbeda dengan RPP yang disusun pada tahap perencanaan, yaitu siswanya mampu memiliki empat keterampilan bahasa yang ideal, yaitu keterampilan membaca, menulis, berbicara, dan mendengarkan.

Temuan diatas diamini oleh Makruf (2016) bahwa berlandaskan sejumlah penelitiannya banyak guru Bahasa Arab madrasah, pada pelaksanaan pembelajaran Bahasa Arab tidak mengimplementasikan pembelajaran Bahasa Arab dengan bahasa pengantar Bahasa Arabnya secara langsung. Pada umumnya, mereka lebih cenderung mengajarkan Bahasa Arab secara pasif, yakni pemahaman qawa'id dan qira'ah. Proses pembelajaran Bahasa Arab yang kurang menekankan pada keterampilan produktif terutama berbicara. Faktornya adalah belum semua pengajar menggunakan Bahasa Arab sebagai bahasa pengantar dalam pembelajaran. Hal ini disebabkan kemampuan peserta didik masih kurang mencukupi untuk berkomunikasi dalam Bahasa Arab.

\section{Hasil Belajar Manajemen Pembelajaran Bahasa Arab}

Hasil belajar yang telah diraih dalam pembelajaran Bahasa Arab yang pertama ialah ada sejumlah kecil peserta didik yang telah bisa membaca teks Bahasa Arab dengan cukup lancar. Hasil selanjutnya adalah peserta didik bisa menyusun kalimat sejalan dengan kaidah yang telah diajarkan. Dan hasil ketiga adalah beberapa peserta didik, meskipun tidak terlalu banyak, bisa berbicara Bahasa Arab dengan kaidah yang baik dan benar. Apabila ditinjau dari hasil belajar peserta didik dalam pembelajaran Bahasa Arab pada evaluasi akhir semester mengalami pencapaian sebesar 71\%.

\section{Kesimpulan}

Perencanaan pembelajaran Bahasa Arab di MTsN 11 Kabupaten Cirebon dibuat berlandaskan pada silabus/RPS kurikulum Bahasa Arab dan guru mata pelajaran Bahasa Arab dituntut untuk dapat mengembangkan kurikulum dan RPP yang telah dibuat agar tujuan pembelajaran tercapai sejalan dengan apa yang diinginkan. Namun hal ini masih kurang terlaksana dengan baik. Pembelajaran lebih banyak ditekankan pada membaca dan mendengarkan. Sementara itu, berbicara dan menulis kurang diintensifkan. Evaluasi pembelajaran dari kepala sekolah dilaksanakan dengan melihat RPP, strategi yang 
diterapkan, dan evaluasi guru terhadap aktivitas pelaksanaan pembelajaran. Selain itu, guru juga memiliki peran dalam mengevaluasi siswa melalui ujian tulis, ujian lisan dan juga dinilai dari formative test agar guru mengetahui rata-rata hasil balajar peserta didik apakah meningkat atau menurun setiap pembelajaran. Faktor penunjang kegiatan pembelajaran Bahasa Arab di MTsN 11 Kabupaten Cirebon adalah kualifikasi pendidik. Sementara itu, yang menjadi kendala adalah faktor guru dalam membangun pembelajaran efektif, kurangnya minat peserta didik dan media pembelajaran kurang mencukupi dan kurangnya penekanan pada pembelajaran Bahasa Arab secara aktif. Hasil yang sudah dicapai adalah sebagian kecil peserta didik sudah dapat membaca teks Bahasa Arab dan menyusun kalimat sejalan dengan kaidah yang telah dipelajari, sebagian peserta didik bisa berbicara Bahasa Arab dengan aturan-aturan bahasa yang baik dan benar, dan pada evaluai akhir semester mencapai $71 \%$.

\section{Referensi}

Asep Kurniawan. 2018. Metodologi Penelitian Pendidikan. Bandung: Remaja Rosdakarya.

Amirudin, Syarifudin Basyar, Muhammad Akmansyah, Subandi, Sulthan Shahril. 2020. "Arabic Learning Management at Islamic Boarding Schools in Lampung." Tadris: Journal of Education and Teacher Training 05(01): 97-109.

Baalbaki. 2006. "Visual Influences on Arabic Linguistic Sciences." The Medieval History Journal 9(1): 37-61.

Baharuddin. 2014. “Pesantren Dan Bahasa Arab.” Jurnal Thariqah Ilmiah 1(1): 16-30.

I. Badrudin. 2017. "Manajemen Pembelajaran Bahasa Arab Berbasis TIK Di Madrasah Aliyah Daarul Uluum Majalengka." Manageria: Jurnal Manajemen Pendidikan Isla 2(1): 155-67.

Idrus. 2019. "Evaluasi Dalam Proses Pembelajaran." Adaara: Jurnal Manajemen Pendidikan Islam 9(2): 920-35.

Indonesia, Menteri Pendidikan dan Kebudayaan Republik. 2013. Peraturan Menteri Pendidikan Nasional Dan Kebudayaan Republik Indonesia Nomor 65 Tahun 2013 Tentang Standar Proses Pendidikan Dasar Dan Menengah.

Indonesia, Presiden Republik. "Peraturan Pemerintah Republik Indonesia Nomor 19 Tahun 2005 Tentang Standar Pasional Pendidikan." https://peraturan.bpk.go.id/Home/Details/49369/pp-no-19-tahun-2005. 
Kabeyi. 2019. "Organizational Strategic Planning, Implementation and Evaluation with Analysis of Challenges and Benefits for Profit and Nonprofit Organizations." International Journal of Applied Research and Studies 5(6).

Karmila Andriana. 2015. "Urgensi Perencanaan Pembelajaran Bahasa Arab Dalam Pendidikan Di Sekolah." Konferensi Nasional Bahasa Arab: 188-98.

Kesuma. 2017. "Refleksi Model Pendidikan Pesantren Dan Tantangannya Masa Kini." Jurnal Keguruan Dan Ilmu Tarbiyah 2(1): 67-79.

Makruf. 2016. "Manajemen Integrasi Pembelajaran Bahasa Arab Di Madrasah Berbasis Pondok Pesantren." Cendekia 14(12): 267-80.

Muhammad Afandi, Badarudin. 2011. Perencanaan Pembelajaran Di Sekolah Dasar Dengan Memasukkan Pendidikan Budaya Dan Karakter Bangsa. Bandung: Alfabeta.

Nginayatul Khasanah. 2016. "Pembelajaran Bahasa Arab Sebagai Bahasa Kedua: Urgensi Bahasa Arab Dan Pembelajarannya Di Indonesia." An-Nidzam 3(2): 39-54.

Nilan. 2009. "The 'Spirit of Education' in Indonesian Pesantren." British Journal of Sociology of Education 3(2): 37-41.

Nurul Hidayatul Amalina, Muh. Nashirudin. 2017. "Analisis Proses Pembelajaran Bahasa Arab Pada Tingkat Tsanawiyah Di Pondok Pesantren Ta'mirul Islam." urnal Tatsqif: Jurnal Pemikiran dan Penelitian Pendidikan 15(2): 173-90.

Badan Standar Nasional Pendidikan. 2007. Permendiknas Nomor 41 Tahun 2007 Tentang Standar Proses. Jakarta: BNSP.

Raihani. "Report on Multicultural Education in Pesantren." Compare: A Journal of Comparative and International Education 42(4): 585-605.

Ridho. "Evaluasi Dalam Pembelajaran Bahasa Arab." An-Nabighoh 20(1): 19-44.

Rofiqah, S. A., Widayanti, \& Rozaqi, A. 2020. "Thinking Aloud Pair Problem Solving (TAPPS) Method: The Effect of Understanding Physics Concepts and Communication in High Schools in Indonesia." Young Scholar Symposium on Science Education and Environment 2019: 1-8.

Suci Ramadhanti Febriani dan Rizka Widayanti. 2020a. "Design of Arabic Learning for Senior High School in the 21 St Century." Jurnal Al Bayan Jurnal Jurusan Pendidikan Bahasa Arab 12(1): 1-2.

- - 2020b. "Improvement Of Arabic Language Tearcher Competency Based On Multiple Intelligences." Jurnal Al Bayan Jurnal Jurusan Pendidikan Bahasa Arab 12(1): 1-2.

Supinah, Markaban, Hanan Windro Sasongko, dan Fadjar Noer Hidayat. 2008. Penyusunan Silabus Dan Rencana Pelaksanaan Pembelajaran (RPP) Matematika SD Dalam Rangka Pengembangan KTSP. Yogyakarta: Departemen Pendidikan Nasional, Direktorat 
Jenderal Peningkatan Mutu Pendidik dan Tenaga Kependidikan, Pusat Pengembangan dan Pemberdayaan Pendidik dan Tenaga Kependidikan Matematika, Pusat Pengembangan dan Pemberdayaan Pendidik dan Tenaga Kependidikan Ma.

Syatriadin. 2018. "Konsep Manajemen Pendidikan Islam Bagi Peningkatan Mutu Pendidikan Sekolah." Al-Furqan: Jurnal Studi Pendidikan Islam 6(2).

Wati Oviana. 2018. "Pengembangan Rencana Pelaksanaan Pembelajaran Berbasis Pendekatan Saintifik Oleh Guru SD Dan MI Di Kota Sabang." PIONIR: Jurnal Pendidikan $7(1): 1-16$. 